\title{
COMO SE ESTÁ ENSINANDO A NOSSA LÍNGUA
}

JOSÉ DE SÁ NUNES

Da capital de São Paulo "Bancário" me envia alguns recortes da "Folha da Manhä" com respostas a consultas feitas a respeito de ortografia, prosódia, etimologia e sintaxe, e a cada uma delas faz observações mui sensatas em sua longa missiva. Vejamos as respostas.

\section{ARREAR e ARRIAR.}

"Ambos os verbos têm a mesma pronúncia e a mesma grafia" é o que diz o gramático em a "Folha da Manhã" de 23-VI1954.

Isso porque o "Pequeno Vocabulário Ortográfico" de 1943 e o "Vocabulário Ortográfico Resumido" de 1947 consignam "arrear" com a significação de "afrouxar", "aparelhar", "pôr arreios a", e "arriar" na acepção de "abaixar", "inutilizar", não obstante haver Gonçalves Viana registrado no seu "Vocabulário Ortográfico e Remissivo" os dois verbos com a mesma grafia: "arrear". Entretanto, ele arrolou também "arriação", com "i", e "arriação" é o acto de "arriar", não de "arrear". Ao inserir os verbos no vocabulário de 1943, considerei em que no espanhol existem as duas formas: "arrear" no sentido de "pôr arreios a", "adornar", e "arriar" com os significados de "abaixar", "amainar"; que no catalão, igualmente, "arriar" quer dizer "amainar", "abaixar" (a vela da embarcação). Ao inscrever os termos no vocabulário de 1947, um com " $e$ ", outro com " $i$ ", o meu insigne colega Prof. Dr. Rebelo Gonçalves nada objectou, mau grado havê- los averbado no vocabulário de 1940 exactamente como o fizera Conçalves Viana; e no seu "Tratado de Ortografia" faz notar a 
homofonia de "arrear" — "pôr arreios a", "aparelhar", "enfeitar", e "arriar" — "abaixar (velas, bandeiras)", "afrouxar (uma escota), etc." " "inutilizar (compartimentos destinados à evaporação)", "desistir". (V. op. cit., pág. 114.)

Agora vem o cego-mor da filologia engarrafada a incutir no espírito de quem o leva a sério que "ambos os verbos têm a mesma pronúncia e a mesma grafia." ! Sua alma, sua palma.

\section{"FLORES" ow "FLÓRES"?}

Fui eu o primeiro em levar a mal o supervisor do "Vocabulário Ortográfico Brasileiro" por haver posto acento circunflexo em "flores", em vista de ter eu consignado este plural sem acento gráfico em o "Pequeno Vocabulário" de 1943. (Vide "Jornal do Comércio" de 15 de Novembro de 1953.)

Um homem que vive no escuro, como os morcegos, e nada lê que possa esclarecê-lo, garatuja a "Folha da Manhā" de São Paulo, edição de 17 de Junho de 1954, dizendo esta inverdade: "Quanto a flôres e flores o caso é daqueles da chinesice dos tais inventores de suplícios imaginários: acham que se deva escrever flôres para distinguir do verbo flores quando tal forma verbal nunca é empregada ..."

Isso não é comigo, porque nem no vocabulário de 1943, nem no de 1947 arrolei "flôres"; isso é com o supervisor do tal vocabulário ortográfico brasileiro, e lá se avenham os dois.

\section{"CURTIR" ou "CORTIR" ?}

Assim o vocabulário de 1943 como o de 1947 dão "curtir", grafia idêntica à espanhola e confome à pronúncia normal não só dos Brasileiros, senão também dos Lusiadas. "Cortir", com "o", é dos tempos em que se escrevia "molher". "agoa" (água), etc.

Mas o consultor da "Folha da Manhā" (17-VI-54) acha que "entre cortir e curtir não há diferença de grafia". La Palisse não diria melhor. E acrescenta: "Os dicionários mais antigos, v. g. o de Cândido de Figueiredo, 2. ${ }^{\circ}$ edição, ainda trazem cortir". E finaliza: "Não há erro algum em tomar a forma antiga".

Quando é que haverá erro para um cego-mor? Se a orto- 
grafia oficial manda grafar "curtir", por que é que não se erra quando ela é desrespeitada? Pelo visto, o erro é que é o certo para os "morcegos gramaticais".

\section{"PIUM-I" ou "PIUMHY"?}

Afirma o referido cego-mor ("Folha da Manhã" de São Paulo, edição de 24 de Junho de 1954): "A denominação geográfica, de origem tupi, Piumhy, foi assim grafada com o recurso do $\mathbf{h}$ para impedir que o $\mathbf{m}$ se ligasse ao $\mathbf{y}$, dando a pronúncia errada Piumy (Piu-mi), forçando o leitor à verdadeira pronúncia: Pium-i. Veio o aranhol da reforma ortográfica e mandou suprimir aquele h interno e surgiu o problema".

Não é verdade. Isso é um aleive, sobre ser a demonstração mais palpável de que o cego-mor não conhece a luz do Sol.

Logo depois de publicado o decreto $n .^{\circ} 20.108$, de 15 de Junho de 1931, um consulente mineiro escreveu-me para me pedir the ensinasse a escrever pela nova ortografia o nome de sua terra "Piumhy". Respondi-lhe que, seguro de errar, grafasse "Piüir" ("u" tilado e "i" com acento agudo). Depois, em 1944, tendo eu recebido a incumbência oficial de passar para a ortografia de 1943 todos os topónimos brasileiros para a obra "Divisão Territorial do Brasil", do Instituto Brasileiro de Geografia e Estatística, fixei aquela grafia — "Piüi" (" $u$ " com til e "i" acentuado), como pode ver-se a págs. 49 e 184 da edição de 1945.

A grafia "Pium-i" pode representar a pronúncia do vocábulo, mas nunca a sua maneira correcta na escrita do Idioma, pois não há preceito nenhum que mande grafar uma palavra com uma das suas silabas separadas por hifen. "Pium-i" é forma esquipática, indigna de ser adoptada.

\section{"HIER6GLIFO" ou "HIEROGLIFO"?}

Lê-se na "Folha da Manhã" de São Paulo, edição de 17-VI-1954: "Quanto a hieroglifo a pronúncia corrente é paroxitona".

Não é assim que se deve responder a que deseja saber a verdadeira prosódia de uma palavra. Impende mostrar-lhe que o étimo recomenda se pronuncie "hieróglifo", e assim é que a proferem os sabedores, os doutos, os que têm obrigação de saber a razão 
das coisas. Cumpre cientificá-lo de que o vocabulário oficial traz a palavra com acento na antepenúltima sílaba, e, pois, é proparoxitona. Releva patentear que todos os bons dicionários da Língua a registram como tal, e não como paroxitona. E é dever do consultor explicar-lhe porque é esdrúxula, e nāo grave.

\section{"EDITAR" ou "EDITORAR"?}

A "Folha da Manhã" paulistana trouxe, em sua edição de 25 de Junho deste ano (1954), uma lengalenga sobre a forma "editorar". Convém transcrever este pedacinho: "Acharam que eu não estava certo só porque tal verbo aparece nos dicionários e foi adoptado por Mário Barreto".

Dessarte procedem os leguleios e rábulas chicanistas. Só vêem nos escritos alheios o que lhes apraz, e dão como não escrito o que lhes despraz.

Não foi alegado apenas que o verbo "editorar" se acha inscrito nos dicionários e foi adoptado por Mário Barreto: alegou-se a opinião de Silva Túlio e citou-se exemplo de Camilo; mostrou-se que "editar" é considerado galicismo por alguns, e que "editorar" é muito mais bem formado.

Pena é que Mário Barreto não possa falar nem escrever ! Nunca deixou ele de usar, juntamente com esse verbo, o "editar". Porque a verdade é esta: nāo se deve repudiar esta forma, conquanto estigmatizada de francesia, para se empregar apenas aquela: ambas as duas se utilizam, uma a par da outra, a bem da variedade e riqueza do estilo.

Castelo Branco fez uso de "editorar" não sòmente em "A Queda de Um Anjo", mas também nas "Noites de Insônia", VII. págs. 52 e 92, como indica Figueiredo no seu dicionário $\left(6^{\circ}\right.$ ediçâo).

O que é de espantar na resposta do consultor é que ele chama de "morcegos da gramática" (stultorum infinitus est numerus) os que não lêem pela sua cartilha - verdadeira colcha de retalhos ... alheios.

Fujamos da casta irascível de certos gramaticões! 


\section{ORIGEM DE "ESTILINGUE".}

"Esta arma de arremesso, espécie de bodoque, espécie de funda, já está dicionarizada pelo Pe. Teschauer, "Novo Vocabulário Nacional". A formação, porém, etimológica ainda não foi explicada, ao menos, quanto me consta". Eis ai o que se escreveu na "Folha da Manhã" paulista de 5 de Junho de 1954.

Informo o distinto consultante de que não a arma, porém a palavra "estilingue" está dicionarizada não só por Teschauer, senão ainda por Gustavo Barroso e Hildebrando Lima no "Pequeno Dicionário Brasileiro da Língua Portuguesa", pelo menos desde 1939, e Cândido de Figueiredo, se me não engano desde a $5 .^{\circ}$ edição do seu "Novo Dicionário da Língua Portuguesa". Além disso, o vocábulo está arrolado no "Pequeno Vocabulário Ortográfico" de 1943 e no "Vocabulário Ortográfico Resumido" de 1947.

Quanto à sua origem, do inglês "sling", veja o que escrevi em "Chácaras e Quintais", n. ${ }^{\circ}$ de 15 de Fevereiro de 1937, pág. 205.

\section{"PASSAR REVISTA A" ou "PASSAR EM REVISTA O" ?}

Defendendo o galicismo sintáctico "passar em revista", expressão verdadeiramente acirológica, escreveu o consultor da "FoIha da Manhã" de 24 de Junho do ano actual (1954): "Desde que esta ou aquela construção seja mais expressiva. para o caso particular do escritor, poderá usar dela como quiser". De maneira que um escritor incorrecto, galicista, desleixado e preguiçoso, julgando que tal construção lhe parece mais expressiva, apesar de errônea ou estrangeirada, deve lançar mão dela, sem indagar da sua legitimidade ou da sua conveniência . . . Absurdo maior da marca!

Se fosse verdadeiro esse "poderá usar dela como quiser", já não haveria necessidade alguma de se estudar a Língua nem de se aperfeiçoar o estilo. Quem quiser escrever para o público outra coisa não tem que fazer senão lançar ao papel as palavras e construções que se the afigurem expressivas, sem ligar a mínima importância às leis da linguagem, aos requisitos do bom estilo e ao código disciplinar do Idioma!

Esse passa-culpas, que ora se mostra de uma indulgência cri- 
minosa para com os francesistas e solecistas, nem sempre se manifesta com igual ânimo em relação a galicismo e acirologias. Costuma responder segundo a simpatia ou a antipatia que vota àquele que escreveu o que the põe sob os olhos, ou vive a catar palavras e construções dos que lhe fazem sombra, a fim de, fantasiando consulentes, vir de encontro à opinião deles.

Sei perfeitamente qual o motivo que o moveu a defender o francesismo "passar em revista", - defesa que recomenda mal o anatematizador de galicismos sintácticos quais estes: "Uns choram enquanto que outros riem". _ "Saltar aos olhos". _ "Isto vem a propósito". - "Comandante em chefe". Etc.

"Passar em revista" é expressāo tida por galicismo pela maioria dos gramáticos e vernaculistas, se bem que em francês se diga correctamente "passer la revue", como correctamente dizemos "passar revista à tropa"; mas é preciso convir em que a preposição "em" não tem por onde se lhe pegue. "Passar revista à tropa", sem embargo da disonância notável em "ta à tro", é construção vernácula que bem se compreende; mas "passar em revista à tropa" ou "passar a tropa em revista" é coisa ininteligivel à luz gramatical. Qual o papel ou a função desse "em"? Os que pouco se importam com a Gramática certamente não se incomodam com uma preposição de mais ou de menos. Mas "escrever sem gramática é uma hediondez insofrível". Já tenho dito e redigo que os inimigos da Gramática se assemelham aos pecadores que odeiam o Catecismo e a Bíblia, e mais se parecem com os delinquentes que têm horror ao Código Penal, à polícia e ao juiz. E note-se bem isto: os que maldizem a Gramática e maldizem dos gramáticos são os que mais erram, porque ignoram aquela e não ouvem a estes.

De exemplos de alguns escritores que não escrupulizam em usar de "passar em revista o" não me espanto nem me escandalizo, porque sei quanto é falível a perfeição humana; mas o que releva é pôr de sobreaviso os que desejam falar e escrever bem, ante os quais é dever do professor apresentar modelos como estes:

De Garrett: "O certo é que ali com efeito passara o imperador D. Pedro a sua última revista ao exército liberal." ("Viagens na Minha Terra", 6. edição, vol. I, pág. 68.) 
De Camilo: "Vou passar uma revista ao exército de Itália:" ("Livro Negro de Padre Dinis", 7.॰ edição, I, 116.)

De Rebelo da Silva: "Fr. João Coutinho passava revista minuciosa ao quarto." ("Contos e Lendas", edição de 1873, pág. 102.)

O "Dicionário Contemporâneo" de Santos Valente (edição de 1881) traz este excerto do mesmo escritor clássico: "Os comissários gerais metiam os esquadrōes em forma e o general passava-thes revista." (Sub voc. passar.)

De Mário Barreto: "Os regimentos da velha guarda, aos quais iam passar revista,'. . " - "Mas em vão passava eu revista na minha mente a todos os heróis de romance que conhecia." ("De Gramática e de Linguagem", edição de 1922, tomo II, pág. 95.) Quem possui a coleção da "Revista de Língua Portuguesa", pode ler o que escreveu o mestre na pág. 132 do n. ${ }^{\circ}$ XIV.

De Alvaro Cuerra: "Saía a passar nova revista aos carros." ("Revista de Cultura", n. ${ }^{\circ}$ 8, pág. 83.)

De Sousa da Silveira: "Falei na leviandade com que o Sr. Júlio Nogueira faz algumas de suas afirmações. Passemos-lhes revista." ("Ânsia, Tecer e a Ortografia Portuguesa", edição de 1928. pág. 38.)

De Cândido de Figueiredo: "Os exemplos são às dezenas, talvez às centenas. Passemos revista a alguns." ("O Que Se não Deve Dizer", vol. I, 4. ${ }^{\circ}$ edição, pág. 96.) - "Tudo isso se poderá documentar, passando revista, ao menos, a uma dúzia de vocábulos do Léxico." ("Revista de Filologia Portuguesa", São Paulo, n. ${ }^{\circ} 10$, pág. 17.)

Aos analisadores professos não passará desapercebida, por certo, uma construção como esta: "O general passou em revista as forças." Dirá que o verbo é bitransitivo, que o objecto directo é "as forças" e que o indirecto não pode ser regido da preposição "em": corrigirá o período não só por isso, mas também porque "passar as forças" não tem sentido: "O general passou revista às forças." O objecto directo é "revista", e o indirecto "às forças."

Rui Barbosa, com o padre Vieira, preferia dizer "dar revista a". 


\section{"JABUTICABAL" OU "JABOTICABAL" ?}

"Aluno-mestre", de Jabuticabal (São Paulo), faz-me duas consultas: uma sobre ortografia, outra sobre sintaxe. Alguns trechos da sua carta merecem ser reproduzidos: "Por que razão escrevem o nome de minha terra ora com "o", ora com " $u$ " ? E verdade que ninguém pronuncia "Jaboticabal", dando a esse " 0 " 0 valor de "o" aberto nem o de "o" fechado, e sim o de "u", mas aqui quase todos ainda usam essa vogal. Parece-me que "Jabuticabal" está mais de acordo com a pronúncia geral, mas eu desejo saber qual a razão do "u" na escrita".

A razão é porque "Jabuticabal" está de acordo com a pronúncia normal e com a etimologia. A palavra é de origem tupi. Segundo Teodoro Sampaio, provém de "yabuticaba", que significa "gordura de cágado." Pode também ser proveniente de "yabutiguaba", que quer dizer "comida de cágado". Como os termos indigenas, em geral, admitem mais de uma interpretação, outros grandes tupinólogos propōem diversa procedência: Baptista Caetano supõe que a palavra se originou de "yamboticaba", que vem a ser "fruto em botão"; e o grande Mestre Plínio Airosa, que adopta essa interpretação, decompõe em quatro elementos o "yamboticaba" = "yá-mbo-ti-caba", com a significação de "o fruto feito pontas ou botões", ou "o fruto abotoado que nasce grudado aos ramos." O sufixo "al" é português e significa no presente caso "ideia colectiva". Seja "yabuticaba", seja "yamboticaba" o étimo de "jabuticaba", o que ninguém pode negar é que toda a gente pronuncia "bu", sobre estar de conformidade com a primeira interpretação indicada, não há dúvidar de que seja legítima e perfeita a grafia "Jabuticabal".

Todavia, impende ter em vista, quanto à etimologia, as sensatíssimas palavras do Prof. Dr. Rosário F. Mansur Guérios a respeito da aglutinação tupi-guarani, em que os mais ilustres tupinólogos têm claudicado: "O fraco de todos êles", diz o eminente professor, "é a etimologia, como eles a entendem; é a anatomia morfológica e semântica a bel-prazer, mas em suma é lucubração fantasiosa ou acrobatismo". ("Novos Rumos da Tupinologia", Curitiba, 1935, pág. 8).

Devo acrescentar que a ortografia oficial manda escrever "Jabuticabal", com "u", e não com "o." 


\section{“LHE”, SUJEITO DE INFINITIVO.}

A segunda consulta de "Aluno-mestre" é interessantíssima, e sobre ela assaz dissertou em sua missiva o inteligente e estudioso correspondente jabuticabalense. Eis um trecho da sua carta: "Na sua "Língua Vernácula" para a $1 .^{\circ}$ e 2. ${ }^{\circ}$ série, pág. 260, aprendi em 1935 que, "quando o verbo ver rege infinitivo transitivo, o sujeito deste infinitivo, expresso pelo pronome obliquo, pode ser dativo (lhe $=0$ )." Entendi que, assim como o sujeito neste caso pode ser "Ihe" com o verbo "ver", também o pode ser com outros verbos, entre os quais "fazer", e assim tenho praticado sempre, sem que até esta data surgisse alguém que mo levasse a mal. Estava eu nesta convicção, quando ontem li na "Folha da Manhã" de São Paulo, número de 16 de Junho do corrente ano, a seguinte resposta dada a um consulente pelo autor da secção "Questões de Português": "A frase: "Far-lhe-ei pedir perdão" está errada e deve ser: "Fá-lo-ei pedir perdão". Confesso que fiquei perplexo. Tornei a ler a lição, tomei de um lapis e copiei-a com letras grandes: "A FRASE: "FAR-LHE-EI PEDIR PERDAO'" ESTA ERRADA E DEVE SER: "FA-LO-EI PEDIR PERDAOO." Depois, lembrando-me do seu ensino, assentei que deveria escrever-lhe sobre o caso, e aqui estou importunando-o a rogar-lhe que me esclareça bem acerca desta sintaxe."

Assim é que neste nosso desventurado País se "ensina" a língua em que cantou Camões e escreveu Rui Barbosa. Assim é que "honra" um dos mais apreciados jornais de São Paulo um professor que tem assento na Faculdade de Filosofia da Universidade desse glorioso torrão brasileiro. Assim é que procedem os "adiantados", os "progressistas", os "arautos da ciência moderna", os senhores da gramática normativa, que vivem a conspurcá-la em nome da própria "Ciência". Bem clamava Rui Barbosa: "Pobre ciência moderna, quantas ignorâncias e imposturas se não acobertam com o teu nome e a tua fraseologia !"

Pois deveras? ! E crivel que se estampe num jornal da Pauliceia uma lição estapafúrdia como essa? Haverá estudante do curso secundário que ignore tal sintaxe? A gramática expositiva ensina-a; a gramática histórica explica-a; e um gramático forrado de filólogo, meado o século $X X$, tem a coragem incrivel de 


\section{$-106-$}

bradar aos quatro ventos: "A frase "far-lhe-ei pedir perdão" ESTA ERRADA; a forma certa é fa-lo-ei pedir perdão."

Ó manes de Rui Barbosa! ó deuses do Vernáculo !

Pobre Alexandre Herculano, que, ao escrever "O Monge de Cister", ignorava ser erro "far-lhe-ei pedir perdão" e deixou escorregar-lhe da pena o imperdoável solecismo! (Veja-se a pág. 141 do 1.0 tomo dessa obra, $14 .^{\circ}$ edição.)

Infortunado Mário Barreto, que nāo sabia ser inominável erro de regência o "fazer-lhes perder um tempo precioso", que the escapou inadvertidamente na pág. 61 dos seus "Factos da Língua Portuguesa!'”

E me miserum, que ensinei aos meus discípulos ser correcta a frase "nunca the vi afagar uma criança" e thes dei o mau exemplo de escrever "fazer-lhe dirigir a atenção" ! (Cfr. a minha "Gramática Histórica", pág. 86.)

Herculano e Mário Barreto sós? Todos os clássicos e todos os gramáticos que sabem formular preceitos consoantes aos factos da Língua são unânimes em aceitar como correcta a regência que ora se tem por errada. Por não ir muito longe, quero citar exemplos sòmente com o verbo "fazer". cujo objecto directo, expresso pelo infinitivo (ou, segundo outros, formando expressão verbal com aquele), tem como sujeito o pronome "Ihe" em vez de "o." E não lançarei mão de todos os que possuo no meu fichário, porque, se o fizesse, esta resposta encheria uma página de jornal ou dez folhas de revista. Observe o Jabuticabalense a maneira de escrever dos mais insignes padrōes da vernaculidade, assim brasileiros como lusitanos, a começar de Camões até os nossos dias:

"Fazem-lhe a Lei tomar com fervor tanto.

Que pressupôs de nela morrer santo." ("Os Lusíadas", VII, 33.)

"Ao que devia cem pipas de azeite lhe fez assinar escrito de cinquenta." (Filinto Elísio: "Vida de Jesus Cristo", edição de 1854, pág. 202.)

"Então pôs Jesus os olhos em Pedro, e the fez lembrar o passado." (Idem, ibidem, 275.) 
"Em consequência da dura vida que a tirania de Erim thes fazia padecer havia bem vinte anos." (Herculano: "Lendas e Narrativas", 12.0 edição, tomo I, pág. 245.)

"Arrastá-lo-ei a Restelo, aos pés de Beatriz e FAR-LHE-EI PEDIR PERDÁO com lágrimas de sangue." (Idem: "O Monge de Cister", 14. ${ }^{\circ}$ edição, tomo I, págs. 140-141.)

"Uma gargalhada .... fazia-lhe perder a ele uma soma avultada." (Idem, ibidem, págs. 202-203.)

"Para melhor gravar na memória aos discípulos os lugares ... Thes faria compor e reproduzir com giz na pedra ..... os três mapas geográficos." (Castilho: "Colóquios Aldeões", edição de 1879, pág. 20.) ibidem, 49.)

"Fazer-lhes tomar gosto à instrução complementar!" (Idem,

"Era a quem incumbirem as mesmas vias; e fizeram-lhe escrever: a quem incumbir as mesmas vias." (Rui Barbosa: "Réplica", edição de 1904, n. ${ }^{\circ} 290$, pág. 398.)

$E$ atente bem o Jabuticabalense: Não é sòmente quando o infinitivo tem objecto directo expresso por substantivo ou expressão substantivada que o seu sujeito, em semelhante condição, pode ser dativo (lhe ou substantivo regido da preposição "a"): também quando ele é intransitivo, conquanto seja raro, dá-se o mesmo, do que tenho provas excelentes. Mas, non est hic locus.

Felizmente, há em São Paulo mesmo não poucos professores que poderão ensinar ao consultor da "Folha da Manhä" que a frase "far-lhe-ei pedir perdão" não está errada, porém certíssima, e um desses professores é Hernâni Calbucci. Quer oferecer ao consultor um exemplar da prestante obra desse ilustre e mui distinto professor, intitulada "Questiúnculas de Lingua Portuguesa", recomendando-lhe a leitura da segunda metade da página 153 ? Será obra de patriotismo e de misericórdia.

\section{EM QUE PE ESTA O CASO ORTOGRAFICO ?}

Assim me pergunta distinta professora capixaba no final de sua carta sobre assuntos gramaticais e estilísticos. E eu the respondo que a 26 de Março deste ano (1954) foi aprovada a Con- 
venção Ortográfica pela Comissão de Constituição e Justiça do Senado Federal, depois do que, ouvido um dos seus mais ilustres membros pelo diário carioca "Última Hora", destarte se manifestou acerca do projecto oriundo da Câmara dos Deputados, que aprova a referida Convenção: "Aprovado o projecto, que deverá ser apreciado pelo plenário, FICARÁ REVOGADO O "VOCABULARIO ORTOCRÁFICO" DE 1943, feito pela Academia Brasileira de Letras, E ENTRARA EM VICOR O "VOCABULARIO" DO ACORDO DE 1954, que foi uma decorrência da Convenção." (Queira ler isso na edição de 30-III-1954 daquele jornal e, também, as opiniōes de cinco deputados no meu artigo inserto no "Jornal do Comércio" de 27 de Junho deste ano.)

Então, em todo o Brasil se escreverá como se escreve em Portugal, pois haverá verdadeira unidade ortográfica nos dois paises irmãos e amigos. Ficamos a dever ao Congresso Nacional "o favor de ter evitado uma aventura gráfica que nos faria perder as vantagens da simplificação"; ficamos a dever-lhe o favor de acabar com o caos ortográfico ora existente em nossa Pátria, e que a vem enchendo de vergonha há vinte e dois anos; o favor de acabar com as complicaçōes de se grafarem palavras ora com as consoantes etimológicas a que têm direito, ora sem elas; o favor de felicitar os alunos das escolas, acabando com um sistema de acentuação que prejudica enormemente milhões de filhos e habitantes do Sul, sistema anticientífico, daninho e erróneo, como é o que está consubstanciado no vocabulário de 1943. Afirmar o contrário é querer empulhar os egrégios Senhores Senadores, mas eles são personalidades que se não deixam embair por memtiras e cavilações.

\section{DOIS NEOLOCISMOS.}

Diógenes Correia da Silva, de Niterói, deseja saber qual a origem e a pronúncia de "cinemascôpe" (assim escreveu ele) e "genocídio". A respeito deste último, diz que leu na edição final d'"O Clobo" de 3 de Julho deste ano (1954), ter a significação de "crime contra a massa", e não sabe que vem a ser isso. Vou dizer-lhe o que é 


\section{$-109-$}

\section{GENOCIDIO.}

Carecendo-se, durante a Grande Guerra, de um termo que significasse "extermínio de um povo", recorreu-se ao grego "génos", que entre outros sentidos tem o de "raça", com o sufixo latino "cídio" ("cida" mais "io"), do verbo "caedere", que quer dizer "ferir". "matar", "fazer grande morticínio ou matança", do que resultou "genocídio". Bem vê o consulente que o neologismo nenhum elemento possui que tenha a significação de "crime," e que "massa" nada tem que ver com "raça." Em grego, "crime" é "aitia" ou "drama", e "massa" (povo) é "demos." O neologismo, conquanto seja híbrido, está bem formado por analogia com muitos outros que terminam em "cídio", e pertence à classe dos facilmente formáveis, como "burricídio", "crocodilicídio", "fradicídio", etc. Nesses a vogal final do primerio elemento é " $i$ ", como sucede nos compostos latinos, pois o " $i$ " é quase sempre temático, e nos vernáculos analògicamente; nos compostos gregos, porém, a vogal de ligação é "o" ("gen" mais "o" mais "cídio").

"Genocídio" quer dizer, em suma, "morte violenta da raça" ou, por extensão, "extermínio de toda uma geração".

\section{"CINEMASCOPE".}

Essa palavra é francesa, formada pelas três primeiras sílabas de "cinématographe" e pelas duas últimas de "stéréoscope". Em França, está muito bem o "cinemascope", porém nos países de língua portuguesa o que devemos ter é "cinemascópio", de "cinema" e o final de "estereoscópio".

O meu amigo e distintíssimo confrade Mário Melo já escreveu sobre este assunto na "Folha da Manhä" do Recife, edição de 21 de Junho do ano atual (1954), concluindo por aconselhar a forma "cinemascópio". Da sua crônica discordo apenas em um ponto: o professor Henrique Cretien, da Sorbona, formou o termo não de "kinema", movimento, e "skopein", examinar, porque, se assim fosse, o neologismo viria a significar "exame do movimento"; ele engendrou-o da forma reduzida de "cinématographe" combinada com o segundo elemento de "stéréoscope", visto que o invento consiste na aplicação do estereoscópio ao cinema. 
O estereoscópio, como se sabe, é um instrumento óptico em que se vêem as imagens planas em relevo, isto é, com as três dimensōes - comprimento, largura e altura, como se fossem reais. Ao segundo elemento dessa palavra - "scópio" juntemos o primeiro de "cinematógrafo" ou, melhor, a forma reduzida "cinema", e teremos "cinemascópio", que é o que devemos usar em nossa língua.

\section{TELEVISÃO.}

"Um Amigo do Vernáculo", de Londrina (Paraná), pede-me The dê uma palavra helénica, ou formada de elementos gregos, que substitua "televisão", hibridismo que julga intolerável.

Intolerável ou não, o certo é que o toleram, e o que não tem remédio remediado está.

Difícil não é a composição de uma palavra que diga o mesmo que "televisão"; ei-la; "teleorama", de "têle", longe, e "hórama", visão. Mas, suporá, porventura, o consultante que ainda será possível substituir "televisão" por "teleorama" ? Tente-o, se quiser.

\section{REGENCIA DO VERBO "ULTRAPASSAR".}

De Erexim (Rio Grande do Sul) me veio extensa missiva, da qual extraio os seguintes períodos: "Num artigo que escrevi para um jornal de Porto Alegre se lê este periodo: "A verdade é que tudo isso ultrapassa dos limites da liberdade". Um professor meu amigo chamou-me a atenção para a regência do verbo "ultrapassar", que ele afirma ser transitivo directo, mas eu não me conformei com a sua lição, porquanto estudei três anos o latim, quando seminarista, e sei que nesse idioma "passare" é intransitivo; sendo intransitivo, o seu derivado não pode ser transitivo. Que me diz o senhor?"

Digo-lhe que esse argumento é extravagante. No clássico latim não havia "passare", e a nossa língua não veio do latim clássico. O nosso "passar" veio do latim hipotético "passare", frequentativo de "pandere", que significa "abrir" ("pandere viam" = abrir um caminho); de "abrir", que quer dizer "dar passagem", "deixar passar", veio a significar "ir através". (Cf. o "Dic. Et." de Nascentes, pág. 597.) 
Se o Erexinense diz não se conformou com a lição do professor que lhe chamou a atenção para a regência de "ultrapassar", espero se conforme com a que the vai supeditar o exemplo dos mestres. Atente bem nestes excertos:

"O nec plus ultra, no assunto, está no cacófaton clássico. Esse, ultrapassando às vezes o grotesco, raia na obscenidade, e mergulha na sordidez." (Rui Barbosa: "Réplica", n. 73, pág. 105, edição de 1940.)

"Esta forma não ultrapassa as fronteiras da linguagem familiar." (Mário Barreto: "Novos Estudos da Língua Portuguesa", edição de 1921, pág. 98.)

"E um dos muitos vocábulos cujo sentido ultrapassa os lindes que autorizaria a sua significação etimológica." (Idem: "De Gramática e de Linguagem", edição de 1922, tomo I, pág. 32.) 